\title{
An Animal Turn in Contemporary French Fiction?
}

Un tournant animal dans la fiction française contemporaine?

\section{Sophie Milcent-Lawson}

Translator. Mark Bossanyi

\section{(2) OpenEdition}

\section{Journals}

Electronic version

URL: https://journals.openedition.org/pratiques/10350

DOI: $10.4000 /$ pratiques. 10350

ISSN: 2425-2042

Publisher

Centre de recherche sur les médiations (CREM)

Electronic reference

Sophie Milcent-Lawson, "An Animal Turn in Contemporary French Fiction?", Pratiques [Online], 181-182 | 2019, Online since 15 January 2021, connection on 05 September 2021. URL: http:// journals.openedition.org/pratiques/10350; DOI: https://doi.org/10.4000/pratiques.10350

This text was automatically generated on 5 September 2021.

(c) Tous droits réservés 


\title{
An Animal Turn in Contemporary French Fiction?
}

Un tournant animal dans la fiction française contemporaine?

\author{
Sophie Milcent-Lawson
}

Translation : Mark Bossanyi

"Writing means transforming the impossibility of
living into the possibility of saying..."
Jean Starobinski (1920-2019), L'Encre de la
mélancolie (The Ink of Melancholy) (2015, p. 622) ${ }^{1}$

1 Animals are increasingly present in contemporary fiction, both in central or secondary roles. Whether this relates to post-modern variants of adventure stories where an isolated human re-engages with the natural world (Divry, 2018; Minard, 2016) or postapocalyptic dystopian stories where the relationship between humans and animals plays out with a new distribution of their roles (Message, 2016), or even to the experience of a domesticated animal forced to return to the wild (Garcia, 2010); whether the intention of the novel is to revisit major historical events without omitting the fate of animals (Echenoz, 2012; Ferney, 2003; Joncour, 2018; Audeguy, 2016) or whether the author considers animals on the fringes of contemporary conflicts (Mouawad, 2012; Rolin, 2018); whether it be fantasy stories on the boundaries of animal nature (Sorman, 2014; Germain, 2016; Coop-Phane, 2019), fantasy animals from childhood and from the unconscious mind (Leca, 2019; Wilhelmy, 2018; Sautière, 2018; Lamarche, 2019), or meditations on a world from which animals have disappeared (Chevillard, 2007; Bailly, 2018; Boyer, 2008), or simply texts attentive to a fading animal presence (Raphoz, 2018); whether it be literary activism for the cause of animal welfare in a serious vein (Sorrente, 2013; Del Amo, 2016; Brunel, 2018) or as parody (Pourchet, 2017; Baqué, 2017): animals are returning in force to the narrative imagination in contemporary French literary works of the last few decades ${ }^{2}$.

2 The salient feature of this resurgence is that animal characters are no longer conceived as anthropomorphised projections of humanity, as was the dominant practice in literary tradition, but are now taken seriously and considered in their individuality as 
animals. We are thus witnessing a narrative shift from the human to the animal, with attempts to imagine and render an animal's view of the world and the interior mindscape of each species, with the fictional imagination enriched by recent advances in zoology and cognitive ethology. This animal presence is thus not limited to the emergence of new themes in the narrative material, such as slaughterhouses or species extinction. It expresses literary approaches that contribute to a renewal of the world of fiction, particularly by striving to move away from anthropocentric narrative, taking note of the "end of the human exception" (Schaeffer, 2007).

So, what new narrative forms, what new stylistic and linguistic modulations does this paradigm change induce, moving away from human ubiquity towards an extended community of living beings. How can exploring these new areas of fiction lead to a reconfiguring of the formal components of narrative? Our approach falls within the framework of zoopoetics ${ }^{3}$, this new field of study initiated by Anne Simon ${ }^{4}$, and sets itself the task of exploring the multiple narrative, enunciative, linguistic and stylistic tools used by writers to imagine and represent the diversity of animal worlds.

Here we will focus attention on a body of recent literary works that explore new narrative pathways, particularly by endeavouring to adopt the point of view of an animal. Although "the desire [...] to slip into the skin of an animal" can be described as utopian, the fact remains that "inability to completely abandon human perception and limited access to others do not mean that such a desire is impossible or to be abandoned" (Baratay, 2017, p. 22-23). Numerous works of fiction take up the challenge, such as a work by Stéphane Audeguy entitled Histoire du lion Personne (Story of the Nobody the Lion):

It is absolutely impossible to tell the story of a lion, because there is something unworthy about speaking in anyone else's name, particularly an animal.

It is absolutely impossible to tell the story of the Nobody the Lion, who lived firstly in Senegal and then in France, between 1786 and 1796.

But there is nothing to stop us from trying. (Audeguy, 2016, back cover, translated by M.B.)

5 Here we will set out a few fruitful attempts that provide evidence of this formal research motivated by the desire to move away from anthropocentric narrative towards a poetics of living beings.

\section{A New Paradigm: the End of Anthropocentric Narrative?}

6 In a short programmatic text entitled "Le chant du monde" ("The Song of the World"), which initially appeared in the review L'Intransigeant in 1932 and subsequently in the short story collection entitled Solitude de la pitié (The Solitude of Compassion), Jean Giono wrote:

For a very long time I have wanted to write a novel in which you could hear the world sing. In all of today's books they have given, in my opinion, too big a place to small-minded people and they have neglected to make us perceive the breathing of the beautiful inhabitants of the universe. [...] I know that we can hardly conceive of a novel without humans, as they are part of the world. What is needed is to put man in his place, not to make him the centre of everything. [...] I know that, at times, they have made use of a river to carry the weight of a novel, the silt of its terror, mystery or strength. I know that they have made use of mountains and that every 
day they still make use of the land and the fields. They make the birds sing in the forests. No, what I want to do, is to put everything in its place ${ }^{5}$. (Giono, 1971, p. 536-538)

7 In fact, nature is not simply a backdrop or setting for human adventures in Giono's novels; it is a character that takes part in the plot. But nature is also inhabited: populated by animals, nature provides narrative animal sequences focusing on a mare, a lizard or an otter (Milcent-Lawson, 2014 and 2018a). This narrative programme that strives to "put [humans] in their place" stands against a novelistic tradition that is only interested in the lives of humans. This is what Julien Gracq calls "the cut-flower side of French-style psychological literature" (1961, p. 54).

At the beginning of the 2000s, Éric Chevillard in turn mocked the anthropocentrism of literature:

Novels hardly take any interest in animals. They deal with humans. The biotope of $\mathrm{Mr}$ and Mrs. They are always more or less the apartment block in George Perec's La Vie mode d'emploi (Life: A User's Manual). Novels are the literature of man alone in the world. They substantiate this sinister utopia. Neither hyena, nor cricket, nor hedgehog, nor octopus. Not to mention the golden tanager. Animals only exist in novels as game, like ham. All these stories about humans, over and over, how boring - is it impossible to bring out anything other than humans (this old man) in language? (Chevillard, 2005, p. 17, translated by M.B.)

We might therefore wonder whether now, at the beginning of the $\mathrm{xxI}^{\text {st }}$ century, we are not witnessing an animal turn in French fiction.

\section{Visibilising Animals}

Firstly, there is a huge movement towards making visibilising animals in fiction. This ineffacement or "undeletion" - a word coined by Michel Deguy ${ }^{6}$ - takes various forms, starting with simply mentioning the presence of animals in scenes in novels. The humoristic distance sometimes present when referring to animals is no less evidence of the increased awareness of the diversity of living things, which the novel is now seeking to put across. Hence for example in Maylis de Kerangal's latest novel we find:

The whole population of Montignac and its surroundings climbs the hill, where there were a thousand-odd people on some days in October 1940, inquisitive people, friends, old ladies from the village, the elite of pre-historians, canons and priests, local figures, a procession escorted by a few animals, insects, pollen, microorganisms and other minute beings invisible to the naked eye. (Kerangal, 2018, p. 269 , translated by M.B.)

In other cases, this visibilisation takes the form of an entire chapter devoted to animals alone, such as the chapter in Jean Echenoz's novel 14 (2012, p. 87-94) dedicated to the fate of animals during the First World War. In her novel La Vie est faite de ces toutes petites choses (The Little Things in Life), Christine Montalbetti also devotes a chapter to the animals on board the space shuttle. Far from the heroic myths generally associated with the conquest of space, $C$. Montalbetti endeavours to show how "life is made up of tiny little things" even for astronauts. As a result, it is not surprising to read about the spiders on board the Atlantis:

[...] during the first few days, confused by weightlessness, they tried to spin their webs with an elastic texture which, it has to be said, did not look very impressive. The beautiful layout of the webs previously spun on Earth was now no more than a 
memory. That was exactly what interested our researchers. (Montalbetti, 2016, p. 218, translated by M.B.)

12 Animals are no longer absent from narrative. After the "tiny lives" rehabilitating anonymous people long excluded from the list of fictional characters (Michon, 1984; Rancière, $2017^{7}$ ), they are becoming legitimate characters reclaimed from oblivion. Animals now stimulate the imagination of novelists and are presented as a new area of fiction to be explored:

That evening, [...] I thought about the bitch called Laïka [...] whom we sent to outer space before it was tried with humans [...].

And I wondered what she lived through, all alone in her little vessel, whether there were windows, whether she had seen the whole depth of the sea of space into which her vehicle was taking her, what images went through her loving dog's brain suddenly plunged into interstellar loneliness. (Montalbetti, 2014, p. 73-74, translated by M.B.)

13 In her next novel, Montalbetti returned to the questions that she had only touched on two years previously in Plus rien que les vagues et le vent (Nothing But Waves and Wind):

We can imagine how this could provide the basis for a short story told from the point of view of a dog, or even a candid monologue by the bitch locked inside the capsule, showing the readers her despair, her doubts as to the suspect presence of this puppet that does nothing to alleviate her solitude. (Montalbetti 2016, p. 211-212, translated by M.B.)

However, although this idea for a short story about Laika still stimulates a desire to write, the novelist did not try to follow through. It is as if the story of the thoughts of the canine astronaut is basically a narrative impossibility. The allusion to these new fictional subjects and, even more, the avoidance of making them a reality, are probably the cautious responses of authors who are keen to steer away from the anthropomorphism found in most previous attempts at literary biographies of animals. In this contemporary era, the inner life of animals is conceived as inaccessible, which makes it more important to preserve its mystery rather than to step inside it. Refraining from taking up the task is perhaps in itself a literary gesture.

Animal characters are first and foremost the locus of questioning. This process is constant in contemporary works, where the emergence of an animal presence gives rise to a multitude of questions. Thus, Sylvain Tesson for example writes:

Nevertheless, deep in the woods, the spectacle of the animals is disturbing. How can we be sure that the dance of the midges in the rays of evening light does not have a meaning? What do we know about the thoughts of a bear? And what if the crustacean blessed the cool water, without having any way to make us aware of the fact and without any hope of us detecting it? And how can we measure the commotion among the sparrows greeting the dawn on the highest branches? And why should those butterflies in the midday light not recognise the aesthetic intensity of their dances? (Tesson, 2011, p. 195-196, translated by M.B.)

16 In the work of Marie Darrieussecq, the ubiquitous presence of animals is textually embodied in the obsessive form of questions without answers and things "yet to be written" (Milcent-Lawson, 2019b). Bref Séjour chez les vivants (A Brief Stay with the Living) provides numerous instances of this:

When you think about it, a cow is just as extraordinary as a duck-billed platypus, thought Nore [...] Because if you consider the cow, a cow, as if you're seeing it for the first time, what do you see? [...] - so the cow: how to see a cow for the first time? That is something that should be written about (Darrieussecq, 2001, p. 171-172, translated by M.B.) 
It should be described. Or to see the world in the same way as flies, spiders, cows and platypus do. (Ibid., p. 178-179, translated by M.B.)

The eyes of the octopus and pig are the most similar to those of man. Do they see the world as we do: its lines, its colours? (Ibid., p. 36, translated by M.B.)

In the mystery of animals, Jean-Claude Bailly sees a literary duty that is both an ethical and an aesthetic imperative. He also meditates at length on the gaze animals set upon the world:

For us, it is an effort just to imagine an existence like that of animals, a being in the world that lives without naming, and yet dies having witnessed. [...] in this most beautiful gaze and in those eyes where you can seemingly drown, there remains this obscure film, this impenetrable and non-human impression where intelligence seems a lake, an ancient, tactile perception. It seems to me that writing the script for this producer-less motion film is the task that writers should address. (Bailly, 1997, p. 233, translated by M.B.)

Although animals appear to challenge them, some writers take the plunge, such as Christian Oster, whose novel Loin d'Odile (Away from Odile) starts as follows:

Let's exaggerate. Let's say that there was a time, not so long ago, when I lived with a fly.

This is not a metaphor. It was a real fly and, as for my claim that I lived with it, forgive me, but at the time I did not know or I had forgotten that this dipteran never exists for more than forty-eight hours. In addition, as my life had not amounted to much for several years [...] it was perfectly plausible that when confronted with a fly, I mean a fly that was stubborn, of course, a fly that was solidly entrenched in its brief fly-like persistence, for despite everything I was well aware that its days would be somewhat brief, I should have had the feeling that I was sharing its life or that it was sharing mine. (Oster, 1998, p. 7, translated by M.B.)

19 Oster takes a humorous look at the difficulties involved in the impossible biography of a fly, but he nevertheless takes up the challenge:

In my diary, I sometimes returned to the passages about the fly. On these occasions I tried in vain to reconstitute its biography. Moreover, the fact that it was probably not one and the same fly throughout hardly made my task easier. In any case, there were nothing other than random zigzags, peremptory buzzing and seemingly purposeless take-offs which were fortunately interrupted by substantial lunch breaks, but without anything ever providing the slightest structure or meaning. In the same way, it was impossible to experimentally establish any kind of typical day, or even any kind of typical period in the day, ending with bedtime, for example, or starting at wake-up time.

However, I enjoyed re-reading these passages before getting down to writing the next one. With regard to my fly, I tried to keep to a sort of thread, particularly by following on from the previous episode when starting another one. So, I would take up my fly's story at the place where it had last landed, even though it was not necessarily still there when I got back to writing. From one description to the next, in general and for reasons of plausibility, I endeavoured to establish a link, weaving a sort of web running through all the episodes, in the hope that my fly would end up getting caught. But basically, it escaped me. (ibid., p. 33-34, translated by M.B.)

Alongside the humour, mockery and ironic distance, another vein of the animal presence in recent fiction is closer to elegy and lyricism. In this respect Catherine Coquio (2011, p. 276) refers to "a discourse of farewell and mourning, oscillating between elegy and eschatology", an attempt "to ward off the spectre of a form of loneliness that is new to the human species". In this geological era of the Anthropocene, in which the human footprint is altering the balance of the biosphere, the threat of the mass extinction of a large number of species assigns a new role to 
literature in species conservation. As Chevillard writes (2014, p. 21), "better than a zoo, literature has the role of conserving animal life, precisely merged here with lexical life, itself no less threatened".

This is the reason why, alongside animal biographies (Baratay, 2017) retracing the life of an animal who, endowed with a name, foregoes the anonymity of the species and is individualised in a life experience made into the subject of narration and fiction (Milcent-Lawson, 2017, p. 95-96), the very memory of species names is now regularly the object of imaginative reverie.

\section{Animals "reported as disappearing"8}

\section{Conservation Literature: the Poetics of Lists}

One of the oldest ways animals have been present in literature is in lists of names. A list can celebrate a teeming presence, as when the neo-Latin poet Ausonius (310-395 BC) listed the fish of the Moselle (Eco, 2009, p. 55-57), or it can adopt the elegiac tone suitable for the fragile memory of a treasure on the brink of extinction. This is the case with Bailly for example:

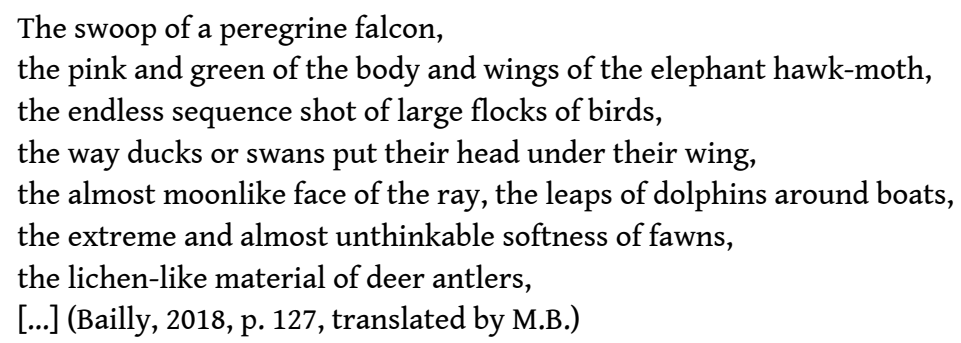

Bailly comments in the following terms: "This is not a poem, but maybe it is a fragment and hence a fragment of the poème de la nature (poem of nature)" (ibid., p. 128). This series of snapshots representing animals sketched from life, short scenes where a thought is followed by a sensation or an image associated with an animal, extends the practice of those "Breughel-like animal scenes" that are so characteristic of Giono's nature writing (Milcent-Lawson, 2018a, p. 212-213). These short sequences that juxtapose so many scenes focusing on animal characters, each occupied with its task, bring to mind the Flemish artist's compositions showing milling crowds of human characters. But the poetics of lists is also embodied in pure series of animal names and other lexical reveries, occurrences of which are found in numerous works in our corpus. Bailly defends the fascination exerted by lists (Milcent-Lawson, Lecolle, Michel, 2013):

Nonethless, with regard to names, that is, at the very heart of lexical profusion, animals (and animal names) ignite a crackling and, with them, it is as if the prodigious diversity of living things was making itself heard, as if it was breaking through the crust of meaning in language in order to produce a fuller meaning, vanishing and incipient at the same time, a meaning that not only would not intimidate the silent contemplation of Plotinus, but which would be its direct emanation: something that is perceivable in the strange pre-phrasing of lists where a language that is hardly spoken and almost never written is sustained, which would retain in itself something of Adamic naming, minus the desire for control. (Bailly, 2018, p. 129, translated by M.B.)

24 J.-C. Bailly (ibid., p. 130) also gives a list of names of North-European freshwater birds to read, a brief extract of which is given here: "[...] gadwall, garganey, red-crested 
pochard, common pochard, common eider, common goldeneye, smew, common merganser, Eurasian bittern ...".

For his part, V. Novarina (1987, p. 321-328) contemplates emerging animals, opting at the end of his Discours aux animaux (Speech to Animals) to include a long litany composed of 1111 names of bird species, a list that is unique in that it contains only words coined by the author. Indeed, so plausible are the names from a morphological point of view that only an ornithologist could spot this detail: "the sparaglite, the éternusse, the zalou, the ouviotte, the pécol, the niveuse, the omphre, the dansereau, the lorange, the lusine, the lidancelle, the bicol, the rusat, the clindre, the délicorne, the vire-gifre, the voltisque, the jappion, the toune, the muriette" (ibid., p. 327).

In short, everything revolves around the term "animot", to use Derrida's neologism (2006). By means of this "imaginary word that contravenes the laws of the French language" (ibid., p. 65), the philosopher "coins a word in the singular ('animot') that sounds identical to the plural noun 'animaux'10" (ibid., p. 73), as a protest against what is presupposed by the general singular of this word, the "Animal", i.e. "The entire animal kingdom except humans" (ibid., p. 65). The scriptural form of the list, which Bailly (2018, p. 130) closes with suspension marks and by the wording "And so on, ad infinitum", reflects this "irreducible multiplicity of life" (Derrida, 2006, p. 65), "an enormous multiplicity of other living beings that do not allow themselves to be in any way homogenised, except through violence and self-serving ignorance, within the category of what we call animals" (ibid., p. 73). In essence, the list of animal names is a poethical gesture, combining ethical duty and poetic creation: "naming, this 'undeletion"', as Raphoz puts it (2018, p. 19).

\section{Ubi sunt? Stating Absence}

"Every animal that disappears takes a secret with it and, when an entire species goes extinct, a password is lost", Bailly has one of his characters say in Sur le vif. Fable mélancolique sur le déclin des espèces sauvages (From Life: A Melancholy Fable on the Decline of Wild Species ${ }^{11}$. Reverie inspired by the word gives way to meditation about an animal that has become absent from our lives: "The word cow referred both to a constellation of stars and to the animal promised to our slaughterhouses", writes Frédéric Boyer (2008, p. 50). The animal vanishes, leaving behind only its name and, as always, unanswered questions: "You miss the animals. They are far away. They are on the other side. They are behind. They are beyond. After. Towards. On the side of. Where? Where are they? Where are the animals?" (Rosenthal, 2010, p. 27.)

However much of a parody, a real funeral oration is delivered by É. Chevillard in Sans l'orang-outan (Without the Orang-utan):

How sudden this absence is! They were there, but they no longer are. A hole in the place where they were. Everyone goes about their business in town, on the edge of this gaping abyss, as if nothing had happened. Am I alone in knowing of their disappearance? Yet I am not inventing this new languor! (Chevillard, 2007, p.11, translated by M.B.)

As the narrative itself withdraws, it leaves behind a fragmented form born of exhaustion and erasure. The narrative breaks down into verses, leaving only snapshots, aphorisms, as in F. Boyer's little book laconically entitled Vaches (Cows) (2008). The book opens with this strange question: "but who were the cows?" (ibid., p. 11). The text takes the form of a philosophical meditation imbued with sufficient humour and derision to 
defy the ridicule elicited by daring to use an elegiac tone to describe these "heavy acrobats" (ibid., p. 56) that deserted the countryside for industrial livestock farms: "Inexplicably, the words 'I am a cow' weigh heavy on our heart" (ibid., p. 40); "In every cow there is someone to kill" (ibid., p. 17).

These few lines from the book are enough to reveal one of the recent linguistic innovations connected to the animal turn in contemporary literature, illustrated here by Boyer, among other possibilities: extending the scope of those pronouns conventionally reserved for humans to animals. Examples include the interrogative who and the indefinite term someone/somebody, but also the term nobody, as a pronoun or a noun. These lexical and grammatical choices attest to the broadening of the concept of person which, in these works, encompasses such non-human characters as animal characters.

31 Having demonstrated the measurable modulation of the place given to animals in present-day fiction - a tonal, stylistic and even linguistic modulation that in itself already marks a turning point - we shall now identify what strictly narrative innovations develop from this accession of animals to the status not only of motif, but of character and key narrative component in contemporary literature.

\section{Towards An Anthropocentric Narrative Perspective? A Few Zoocentric Narrative Devices}

In her essay on narrative fiction, Marta Krol (2017) puts forward the idea of "anthroporéglage narrative" ("the anthropocentric setting of narrative"). This terminological choice expresses an increasing awareness of the fundamentally anthropocentric nature of narrative, conceived as it is as a product "on a human level ${ }^{12}$ " and intended for a human reader ${ }^{13}$. Although Krol does not envisage the possibility of other "settings" via fiction, her approach at least helps to highlight the exclusively human "perspective-based world" of conventional narrative (ibid., p. 262), entirely determined by human motor-sensory, cognitive and emotional patterns. On the basis of these theoretical considerations, it is our role to track down in these animal sequences the linguistic, enunciative and stylistic features specific to narratives that attempt a zoocentric fictional perspective. Indeed, ever since stories of metamorphoses in Antiquity, authors have enjoyed imagining other experiences of the world beyond the bounds of strictly human perception. More than an exercise in style, these thought experiments have been notably renewed in the contemporary era by efforts to go beyond the human domain and to consider animals as a perceptual and cognitive idiosyncrasy.

\section{The Shift in Narrative Perspective}

According to the dominant theories in narratology (Patron, 2016), the narration must be attributed to an enunciative instance: the narrator. Although an abstract construct embodying the theory of illocutionary pretense, this narrator is posited as human, being considered the speaker of the text ${ }^{14}$. The reader thus makes the default assumption that the text emanates from a human narrator. The opening words of 
Agnès Desarthe's Une partie de chasse (Hunting Party) provide a good example of the effects produced by means of a narrative shift:

I would want to die a natural death. I would like to grow old. Nobody grows old among us. We depart in the prime of our lives.

$[\ldots]$

I would like to be bored, to experience disgust. And then to benefit from the relief of maturity.

I would like to have the time to experience love and the infinite luxury of disenchantment.

[...]

We have no memory. We have no time to accumulate memories and experience. At each birth, the entire species starts from scratch and we run and jump a panic stricken, zigzag course. We have hardly felt the sun on our brows, the warmth of our mother's milk in our gullet, when we have to leave our dwelling, depart, make up the delay inscribed from eternity in our genetic code. Late, late, we are always late. Threat is engraved in each of us. Threat is our fate. (Agnès Desarthe, 2012, p. 8-9, translated by M.B.)

By default, the reader assumes that the narration emanates from a human source and so, logically, that it expresses a human point of view on the reported events. The reader therefore tries to eliminate the identifiable oddities in the opening passage of the novel - Why does the narrator aspire to a natural death? Why does nobody grow old in his family? - by indexing them on some human pathology or psychological explanation. The effect of serialisation, however, gradually leads to another interpretation of the narratorial "I", redirecting the interpretation of clues that were initially considered dissonant and integrating them into a series that gains prominence as the text progresses and starts to make sense (such as the terms "our lineage", "floppy ears" or "gullet"), until the final confirmation: "The lead that shoots out of the rifle the moment I spring out of my burrow" (ibid., p. 10).

Just as the Belgian plastic artist Pascal Bernier, in his "Accidents de chasse" ("Hunting Accidents") series of 2008, overturns the human point of view expressed in the title of the exhibition by exhibiting stuffed animals wearing bandages, so Desarthe reverses the point of view by opening her novel not with one of the hunters, as could be expected from the back cover ${ }^{15}$, but with one of their victims: a rabbit accidentally hit by a stray bullet due to Tristan's clumsiness. However, it should be noted that although the author chooses to put the reader on the side of the prey, she does so as it were without the reader's knowledge. The fictional identification with the narratorial "I" begins to take effect before the reader realises that he/she is identifying with an animal. This narratorial device is not only light-hearted. The opening of this hunting story with "fictional immersion" (Schaeffer, 1999, p.179) in the thoughts of a wild rabbit immediately establishes the way the text is received, even though just afterwards the story reverts to the conventional anthropocentric narrative perspective of human characters. The fact that the thoughts of this rabbit are eminently anthropomorphic in no way detracts from the narrative effectiveness of the ploy and it could even be said that the anthropomorphic device facilitates the phenomenon of fictional identification. Moreover, the novelist seems to be asking us why the representation of the thoughts of an animal should necessarily suppose an inner life that is less rich than that of humans. This is why the intimate thoughts that she attributes to the rabbit are not a pale substitute for human contemplation. By lending it existential anguish, she is projecting 
the assumed - and, incidentally, ironic - image of a sensitive animality that as such is worthy of all the usual resources of inner discourse.

The deliberately delayed identification of the non-human nature of the narrator turns out to be a recurrent ploy in our body of literature, whether related to an isolated sequence or extending throughout the whole text. Notably, we can find it in Vincent Message's science fiction novel (Défaite des maitres et possesseurs (Defeat of the Masters and Possessors), 2016), in which the narrator, initially assumed to be human, reveals its otherness when the reader finds out that it has a human pet. Indeed, the argumentative effectiveness of this contemporary philosophical tale is entirely based on the reversal of perspectives (Milcent-Lawson, 2019a).

Chevillard also uses this enunciative lure in a text entitled "Significant Progress" from the collection Détartre et désinfecte (Descales and Disinfects) (2017). In this text, the narrator evokes his idle everyday life: "My behaviour changed. I was now spending most of my day asleep" (ibid., p. 112) or, further on: "But I only moved in order to give myself some amusement and distraction" (ibid., p. 115). The reader imagines that this narratorial "I" refers to a human storyteller. The identification of the "I" is deliberately delayed as long as possible before it appears in the last lines, in accordance with the narrative logic of short stories with unexpected endings. Only in the last word is the character of the narrator conclusively identified as a cat (or a human metamorphosed into a cat): "Then curls up in its basket, on its cushion, and almost immediately starts purring." (ibid.) This identification gives rise to retroactive comic effects leading to a reinterpretation of some items of information such as "They feed me. At least twice a day, a full plate is put in front of me" (p. 113), or the narrator's disagreements with the dog (ibid.), or even statements such as this: "The caresses that escaped me like wild birds came themselves to meet me. [...] Without fearing the slap that such boldness had often earned me in the past, I could rub up against the legs of the most beautiful women and even slip under their skirts." (ibid.) In fact, only when read back does the text take on all its meaning. Moreover, the readers belatedly realise that they have been part of a thought experiment that has led them unwittingly to identify with a cat for the duration of a short story. Here again, the anthropomorphism pervading the content and form of the cat's narrative is not only assumed, but diverted for the purposes of ironic distance. However, we can see that in these examples the shift in narrative perspective remains an exercise subordinated to a narrative strategy intended far more to trick the reader than to explore the secrets of the inner life of an animal. The point of view is arguably more eccentric than zoocentric.

\section{What is at stake in Zoocentric Narrative?}

\section{Point-of-view Effects Governing Narrative}

Giono again stands out as a pioneer in his use of a narrative technique that takes advantage of the point-of-view effect associated with an animal-centric perspective. The writer opens his novel Batailles dans la montagne (Battles on the Mountain) with a narration in which the centre of consciousness is a wild boar. At this early stage, when starting the story, the reader is asked quite simply to temporarily forego the intelligibility of the world. The point of view of the boar, limited to raw sensations, restricts the field while heightening the mechanisms of curiosity and narrative tension: 
One hour before the end of the night, a boar entered the larch wood through its lower edge. It moved up through the trees. it was covered in mud. It walked heavily with the last of its strength, as if after an extended hunt. it leaned against the trunk of a tree. it rested. It was overwhelmed by terrible, exhausted gasps. [...] No animal of its race had ever come up as far as this. It knew neither these trees nor this ground. It set off again. [...] It wanted to get up as high as possible. It put all of its remaining strength into it. [...] It seemed to be being followed by a mystery. Finally, it fell; it lay down; it stretched out its trotters. It was trembling. It tried to pull itself even higher with all its strength, but could go no further. It closed its eyes. Always the smell of the water. It tried to drive it away by blowing. [...] A sort of dull, continuous sound, not very loud but filled with a hundred deep echoes, made it aware of the height. It smelled the new scent of larch bark. (Giono, 1972, p. 786, translated by M.B.).

Through the focalisation of this narrative, the disaster hitting the valley is perceived in all its inexplicable violence. In delivering raw information through the filter of the sensations of a wild boar in panic, forced by some dark instinct to reach higher ground, Giono leads the reader to infer from this fragmentary information that the valley has been flooded. Beyond the sensory disorientation at work in this innovative experience of fictional identification, this technique lends a unique suggestive power to the narrative exposition of the story.

In the epilogue to his novel Règne animal (Animal Kingdom) of 2016, Jean-Baptiste del Amo makes the same choice of an animal centre of consciousness. In the last pages, the author recounts the flight of a boar by adopting its point of view. Through the bodily experience of "The Animal", the reader is invited to share the discovery of the outside world by a creature whose horizons were hitherto limited to the inside of a barn. While keeping the story in the third person, the internally focalised notations help the reader to share mentally in a non-human sensory experience without sacrificing the precision of literary language:

Another call is guiding it, even more pressing than being in heat; it is the tenuous fragrance of the night that is entering the building through the gaps. [...] It puts its snout up against the crack and, with a single movement of its muzzle, slides the panel along the rail. It takes a few steps forward on the big concrete slab, lifts its head and breathes. The countryside is black and quiet. A tremor of excitement passes through the boar's massive body. [...]

The land extends beyond, glowing and embalmed, harbouring the mist rising from the grass and the roots, from the unknown animals and small prey, the damp bushes and old orchards turned blue by the moon.

[...] The ends of the cut wires dig into its flesh, cutting along the back and sides of its whole body. [...] Drunk with pain, it gallops to the middle of a fallow field. It has never run in its life. It discovers its mass and the strength it needs to muster in order to move. Blood flows from its wounds and runs between its bristles. It stops, stunned by the effort, the new-found freedom and the vibration of the night that its eyes probe with dilated pupils.

[...] It runs for a long time, disoriented by the night, the tumult of fragrances and strange sounds. It slows down, held back by lack of breath, its weight and its painful joints. Accustomed to the concrete and the gratings, firstly it avoids the soft earth, the damp grass and the ditches that may harbour something dangerous. (Del Amo, 2016, p. 414-415, translated by M.B.)

And so the aporia of knowledge makes way for these hypothetical narratives which offer up fictionalised animal lives for the reader's imagination. Whether isolated or more developed, these sequences are emblematic of the nature and the challenges of the animal turn in contemporary fiction. In stories marked by powerful and even sometimes disconcerting sensory qualities, they reflect and embody a way of 
narrating that abandons visual deixis in favour of a mental map dominated by tactile, olfactory and auditory sensations, substituting percepts for concepts; in short, they seek to invent narrative modes that are free of the anthropocentric narrative perspective dictated solely by the human experience of the world.

\section{Stream of Consciousness and its Physiological Variant}

41 In the epilogue to Mal de mer (Breathing Underwater), Marie Darrieussecq imagines an entire narrative sequence focusing on a shark. The hypotyposis effect of this passage results from a present-tense narration that confers great evocative power to this almost dreamlike sequence. But what is remarkable is how the narration bypasses introspective features, restricting its verbalisation to sensory information alone:

The ocean has become the sea, with a swirling current that turns into a swell towards the shore. Warning signals are more and more violent, the flesh thrashes in alarm, water squirts faster under the broad gills. The body rises and falls, the land makes its noise, breaks up the water, rumbles, and growls, huge and still like a predator. Now, even if its tail fin were to arch up to its maximum, the open sea has become inaccessible. The alarm subsides, all is quiet in the big movement of the waves. Fatigue has replaced hunger. The open void under its worn baleens seems to have closed little by little. The sea no longer flows through it. It encounters an obstacle at the bottom of its belly, a dead calm. The muscles no longer have to move to escape this hunger. The body lets itself drift like a buoy. At the bottom, in the hole, giant squid are waiting, large white corpses shuddering with glowing-red discharges of blood. [...] The lateral fins make a final push, the beach is avoided. The cliff is now very close, sending radar signals straight back: a mass of shale, emerging, carved by the water, caves, runnels, faults, magnetic masses and metal fallen from the sky. Its back surfaces, the air is brutally dry, the wind bends its dorsal fin and makes its body list towards the rollers. The sonar now fails to distinguish up from down, north from south. A rock cuts deeply into its leathery skin. Its flanks strike the sand, the waves withdraw; the weight of the muscles slowly suffocate it, the gills collapse under their own size. The ground is coarse, imperious, pressing under its belly; the ground turns under an unflinching sun. (Ibid., p. 115-116, translated by M.B.)

As she has opted for an enunciative scenography with an animal as the focus of perspective, Darrieussecq is forced to return to the stream of consciousness technique (Milcent-Lawson, 2019a and 2019b). But she abandons all vocal effect and any simulation of internal discourse in favour of a mental stream comprising only sensory information. Choosing a zoocentric narrative forces her to imagine another form of inner experience one that is no longer introspective and turned towards the self, but entirely defined by its interactions with its environment (Umwelt ${ }^{16}$ ). In so doing, the novelist achieves the considerable feat of dissociating the vocal and focal components of the story. Narrative voice and point of view, usually bound together in anthropocentric literature, are completely dissociated here. Darrieussecq invents no less than a physiological stream of consciousness.

The animal question generates the appearance in stories of what we suggest naming "animal sequences", present in a growing number of contemporary narrative works. It opens up an exploratory field in narrative studies and has to do with the emergence of formal innovations related to the ambition of moving beyond anthropocentric narrative. Jacques Rancière (2017) has theorised how the entry of simple folk into the fictional worlds from which they were previously excluded contributed to the reconfiguration of the temporality and the narrative modes of literature. Similarly, 
conceptualising an animal turn in contemporary fiction means recognising the inclusion of animals considered as such on the thematic level and as fictional characters and addressing the task of identifying the resulting formal re-orientations. It is also possible to trace a parallel between the narrative innovations represented by attempts to move beyond the anthropocentric narrative perspective in animal sequences and the emergence at the end of the XIX ${ }^{\text {th }}$ century and at the beginning of the $\mathrm{xx}^{\text {th }}$ century of new literary forms linked to the discovery of the subconscious, forms such as inner monologue and stream of consciousness. There is good reason to believe that the dissemination of recent advances in cognitive ethology relating to the mental processes and emotional capacity of animals will not be without repercussions on literary discourse and that this new knowledge will soon open up new imaginary realms. For is it not possible that literary theory, as suggested by Gérard Genette in the opening text of Figures III (1972, p. 11), may take as its subject "not only actual literature, but also the totality of virtual literature"?

\section{BIBLIOGRAPHY}

\section{Quoted works}

AUDEguY, S. (2016). Histoire du lion Personne. Paris: Éditions du Seuil.

BAILLY, J.-C. (2018) [2007]. Le Versant animal. Paris: Bayard.

BAQUÉ, J. (2017). La Fonte des glaces. Paris: POL.

Boyer, F. (2008). Vaches. Paris: POL.

BRUNEL, C. (2018). La Guérilla des animaux. Paris: Alma.

CHEVILLARD, É. (2007). Sans l'orang-outan. Paris: Éditions de Minuit.

CHEVILLARD, É. (2014). Le Désordre Azerty. Paris: Éditions de Minuit.

CHEVILLARD, É. (2017). Détartre et désinfecte. Saint-Clément-de-Rivière: Fata Morgana.

COOP-PHANE, O. (2019). Le Procès du cochon. Paris: Grasset.

DARRIEUSSECQ, M. (1999). Le Mal de mer. Paris: POL.

DARRIEUSSECQ, M. (2001). Bref séjour chez les vivants. Paris: POL.

DEL AMO, J.-B. (2016). Règne animal. Paris: Gallimard.

DESARTHE, A. (2012). Une partie de chasse. Paris: Éditions de L'Olivier.

DIVRY, S. (2018). Trois fois la fin du monde. Montricher: Éditions Noir sur blanc.

ECHENOZ, J. (2012). 14. Paris: Éditions de Minuit.

FERNEY, A. (2003). Dans la guerre. Arles: Actes Sud. 
GARCIA, T. (2010). Mémoires de la jungle. Paris: Gallimard.

GERMAIN, S. (2016). À la table des hommes. Paris: Albin Michel.

GIONO, J. (1972). Euvres romanesques complètes II. Paris: Gallimard.

JONCOUR, S. (2018). Chien-loup. Paris: Flammarion.

KERANGAL, M. de (2018). Un monde à portée de main. Paris: Éditions Verticales.

LAMARCHE, C. (2019). Nous sommes à la lisière. Paris: Gallimard.

LECA, B. (2019). L'Étrange Animal. Paris: José Corti.

MESSAGE, V. (2016). Défaite des maîtres et possesseurs. Paris: Éditions du Seuil.

MICHON, P. (1984). Vies minuscules. Paris: Gallimard.

MINARD, C. (2016). Le Grand Jeu. Paris: Éditions Rivages.

MONTALBETTI, C. (2014). Plus rien que les vagues et le vent. Paris: POL.

MONTALBETTI C. (2016). La Vie est faite de ces toutes petites choses. Paris: POL.

MOUAWAD, W. (2012). Anima. Montréal/Arles: Léméac/Actes Sud.

NOVARINA, V. (1987). Le Discours aux animaux. Paris: POL.

OSTER, C. (1998). Loin d'Odile. Paris: Éditions de Minuit.

POURCHET, V. (2017). Pourquoi les oiseaux meurent. Le Bouscat: Éditions Finitude.

RAPHOZ, R. (2018). Parce que l'oiseau. Paris: José Corti.

ROLIN, J. (2018). Le Traquet kurde. Paris: POL.

ROSENTHAL, O. (2010). Que font les rennes après Noël? Paris: Gallimard.

SAUTIÈRE, J. (2018). Mort d'un cheval dans les bras de sa mère . Paris: Gallimard.

SORMAN, J. (2014). La Peau de l'ours. Paris: Gallimard.

SORRENTE, I. (2013). 180 jours. Paris: Jean-Claude Lattès.

TESSON, S. (2011). Dans les forêts de Sibérie. Paris: Gallimard.

WiLHELMY, A. (2018) [2017]. Le Corps des bêtes. Paris: Grasset.

\section{Theoretical Texts}

BAILLY, J.-C. (1997). Le Propre du langage. Voyages au pays des noms communs. Paris: Éditions du Seuil.

BARATAY, É. (2017). Biographies animales. Des vies retrouvées. Paris: Éditions du Seuil.

CHEVILLARD, É. (2005). "Portrait craché du romancier en administrateur des affaires courantes”. In: Zimmermann, L. (dir.), L’Aujourd'hui du roman. Nantes: Cécile Defaut.

CITRON, P. (1990). Giono 1895-1970. Paris: Éditions du Seuil.

CoQuio, C. (2011). “L'humour ou la gravité. L'animal, mythe épistémologique et attitude littéraire”. In: Engélibert, J.-P. et al. (dirs), La Question animale. Entre science, littérature et philosophie. Rennes: Presses universitaires de Rennes (Rennes University Press), p. 275-299. 
DEGUY, M. (1986). Brevets. Seyssel: Champ Vallon.

DERRIDA, J. (2006). L'Animal que donc je suis. Paris: Galilée.

ECO, U. (2009). Vertige de la liste. Paris: Flammarion.

GENETTE, G. (1972). Figures III. Paris: Éditions du Seuil.

GIONO, J. (1971) [1932]. “Le chant du monde”. In: Solitude de la pitié. Paris: Gallimard, p. 536-538.

GRACQ, J. (1961). “Les yeux bien ouverts”. In: Préférences. Paris: José Corti.

KROL, M. (2017). Pour un modèle linguistique de la fiction. Essai de sémantique intégrée. Villeneuve d'Ascq: Presses universitaires du Septentrion (Septentrion University Press.

MAIRESSE, A. \& SIMON, A. (dirs) (2011). “Face aux bêtes/Facing Animals”. L’Esprit créateur 51 (4).

MILCENT-LAWSON, S. (2014). "Points de vue et discours animaux dans le romanesque gionien". In:

Romestaing, A. (dir.), Mondes ruraux, mondes animaux. Le lien des hommes avec les bêtes dans les romans rustiques et animaliers de langue française ( $\mathrm{xx}^{\mathrm{e}}-\mathrm{XxI}^{\mathrm{e}}$ siècles). Dijon: Éditions universitaires de Dijon (Dijon University Editions), p. 61-72.

MILCENT-LAWSON, S. (2017). “Zoographies. Traitements linguistique et stylistique du point de vue animal en régime fictionnel”. Revue des sciences humaines (Humanities Review) 328, p. 91-106.

MILCENT-LAWSON, S. (2018a). “Chant du monde et paroles d'animaux dans l'œuvre de Jean Giono”. Revue Giono 11, p. 211-233.

MILCENT-LAWSON, S. (2018b). “Du chien confident à l'animal sujet de conscience (Dans la guerre by Alice Ferney)". Symposium Animal Speech , Université Paris (Paris University) 8, 27 Jan. Online: https://www.fabula.org/colloques/document5380.php.

MILCENT-LAWSON, S. (2019a). "Parler pour les animaux: tentatives littéraires contemporaines. Point de vue animal chez Message, Garcia et Darrieussecq” Transtexte(s)/transcultures 13. Online: https://journals.openedition.org/transtexts/1194.

MILCENT-LAWSON, S. (2019b). “Énonciations animales dans l'œuvre de Marie Darrieussecq”. In: Germoni, K., Milcent-Lawson, S. \& Narjoux, C. (dirs), L'Écriture "entre deux mondes" de Marie Darrieussecq. Dijon: Éditions universitaires de Dijon (Dijon University Editions), p. 39-52. MILCENT-LAWSON, S., LECOLLE, M. \& MICHEL, R. (dirs) (2013). Liste et effet liste en littérature. Paris: Classiques Garnier.

PATRON, S. (2016). La Mort du narrateur et autres essais. Limoges: Lambert-Lucas.

RANCIÈRE, J. (2017). Les Bords de la fiction. Paris: Éditions du Seuil.

ROMESTAING, A. (dir.) (2014). Mondes ruraux, mondes animaux. Le lien des hommes avec les bêtes dans les romans rustiques et animaliers de langue française ( $\mathrm{xx}^{\mathrm{e}}-\mathrm{XxI}^{\mathrm{e}}$ siècles). Dijon: Éditions universitaires de Dijon (Dijon University Editions.

ROMESTAING, A. \& SCHAFFNER, A. (dirs) (2014). Animaux d'écritures. Le lien et l'abîme. Romanesques. Paris: Classiques Garnier.

ROMESTAING, A. \& SCHAFFNER, A. (dirs) (2015). “Approches de l'animal”. ELFe XX-XXI 5.

RUEFF, M. (2009). Différence et identité. Michel Deguy, situation d'un poète lyrique à l'apogée du capitalisme. Paris: Herman.

SCHAEFFER, J.-M. (1999). Pourquoi la fiction? Paris: Éditions du Seuil. 
SCHAEFFER, J.-M. (2007). La Fin de l'exception humaine. Paris: Gallimard.

SIMON, A. (dir.) (2012). "Humain/Animal Part 2" (Human/Animal Part 2). Contemporary French and Francophone Studies 16 (5).

SIMON, A. \& BENHAÏM, A. (dirs) (2017). “Zoopoétique: les animaux dans la littérature de langue française ( $\mathrm{xx}^{\mathrm{e}}-\mathrm{XxI}^{\mathrm{e}}$ siècles)”. Revue des sciences humaines (Humanities Review) 328.

STAROBINSKI, J. (2015) [2012]. L'Encre de la mélancolie. Paris: Éditions du Seuil.

UEXKULL, J. Von (2010) [1956]. Monde animal et milieu humain. Translated from German and annotated by C. Martin-Freville. Paris: Payot \& Rivages.

\section{NOTES}

1. All quotations from French texts are translated by Mark Bossanyi.

2. We will limit this analysis to the area of French expression and indeed to French literature. Examining other works from Francophone and foreign literatures, particularly in English, would be fruitful but would require developments beyond the limits of this article.

3. The term zoopoetics was first used by Jacques Derrida (2006, p. 20) in relation to the work of Franz Kafka.

4. A researcher at the CNRS (France's National Scientific Research Centre), a professor in the Arts and Language Research Centre at the École des Hautes Études en Sciences Sociales in Paris (School for Advanced Studies in Social Science) and head of the Animots programme, Simon co-directed the studies entitled "Face aux bêtes/Facing Animals" (2011), "Humain/Animal" (Human/Animal) (2012) and "Zoopoétique" (Zoopoetics) (Simon \& Benhaïm, 2017).

5. Giono will use this title again for his novel Le Chant du monde (The Song of the World), which puts the spotlight on the natural world. He wrongly thought he was borrowing this expression from Walt Whitman's Leaves of Grass.

6. On Deguy's concept of undeletion as a way to counter oblivion, see Rueff, 2009, p. 401 et seq.

7. What Rancière (2017) refers to as the "democratic revolution of fiction" thus extends beyond the human domain.

8. An expression freely borrowed from Deguy: "thinking about the expression 'reported missing', I would say that poetry 'reports disappearance"' (Deguy, Brevets (Patents), Seyssel, Champ Vallon, 1986, p. 25 and quoted by Rueff, 2009, p. 344).

9. This pictorial analogy was put forward by Citron (1990, p. 132).

10. The neologism "animot", a portemanteau word built from the blending of animal + mot (animal + word), is a homophone of the plural form of animal: animaux.

11. An unpublished play written by Gilberte Tsaï for the Nouveau Théâtre de Montreuil in March 2003, submitted under this title to the Society of Dramatic Authors and Composers. (Extract quoted by Afeissa, 2018.)

12. "Another name for this rescaling could be anthropic setting, i.e. the setting of the representation on the scale of human experience." (Krol, 2017, p. 317.) With the process of rescaling defined as follows: "It involves a selection in discourse of entities and their 
attributes such as may be encountered in human experience, given its motor functions and cognitive apparatus: in particular, giving rise to objects of perception." (Ibid.)

13. Krol does not consider that human readers could identify with a non-human protagonist in their imagination. This is why she defines the prefabricated objects of perception as "descriptive effects of reading that provide different sensory attributes of the designated entities and contribute to the representation in the reader's mind of the visible, tactile, auditory and other qualities as he/she would perceive them if he/ she witnessed the scene, or as perceived by a protagonist" (ibid., p. 319).

14. See the contribution of Sylvie Patron and the interview with Brian Richardson on non-natural narratologies in this volume.

15. "There are four of them. Four hunters moving forward through the mists of dawn with their guns and their dogs. Tristan is the youngest. What is he doing in the company of these men from whom he feels so different? Is it to go through a rite of initiation? Or to settle a matter of honour that sets him against one of them? An accident happens. They have to go and find help. The elements get involved and a storm brews. The downpour sweeps everything away, perhaps echoing Tristan's desire to start on a clean slate after a burdened past." (Desarthe, 2012, back cover)

16. According to Jakob von Uexkull (2010), Umwelt designates "the world specific to" each species with its own specific perceptional and actantial space.

\section{ABSTRACTS}

While animal characters clearly belong in a literary tradition dating back from antiquity, contemporary animal characters differ from their fictional predecessors in that they are not conceived as anthropomorphised allegorical projections of humanity, but are taken seriously both in terms of their otherness and in terms of their animal individuality. The purpose of this study is to identify certain narrative, enunciative and stylistic innovations from a body of fictional stories that result from the narrative and ethical shift that they put into practice. In short, the objective is to examine the emergence of a narrative that is no longer anthropocentric, but zoocentric, usually within the limited framework of "animal sequences".

Si le personnage animal appartient à l'évidence à une tradition littéraire qui remonte à l'Antiquité, les personnages animaux contemporains se distinguent de leurs prédécesseurs fictionnels en ce qu'ils ne sont pas conçus comme des projections allégoriques anthropomorphisées de l'humanité, mais pris au sérieux dans leur altérité comme dans leur individualité animales. Cette étude entend dégager d'un corpus de récits fictionnels contemporains certaines innovations narratives, énonciatives et stylistiques résultant du décentrement narratif et éthique qu'ils mettent en œuvre. Il s'agit en somme d'examiner la naissance, le plus souvent dans le cadre restreint de "séquences animalières ", d'un récit non plus anthropocentré mais zoocentré. 
INDEX

Mots-clés: fiction, littérature française contemporaine, animal/animaux, zoopoétique

Keywords: fiction, contemporary French literature, animal(s), zoopoetics

\section{AUTHORS}

\section{SOPHIE MILCENT-LAWSON}

University of Lorraine, Crem, F-57000 Metz, France 